satisfy the boldest and the most ambitious; breadths of uncertainty such as the most speculative may find room to range in; facts of plain value that may satiate the merest utilitarian; opportunities for experiment enough for the most ingenious; laws large enough for the most capacious-deep enough for the most profound. And in respect of virtue our life is full of occasions-nay, rather, of inducements for it. We live in the daily study of that which we believe to be the most perfect and the most elaborate of God's works-marvellous in its perfection, marvellous in its decay, and in its final change. Therefore, in our common tasks we may cultivate an habitual reverence and homage, and may find constant aids to faith in the analogy between what we see of the earthly life, and what, as revealed to us, we believe of the heavenly. We live amongst the suffering, and every one who needs our help may clain to be an object of our compassion, or may exercise our gentleness and patience. We live amongst the dying, and every day shows to us, more clearly than it does to other men, the need of watchfulness and Christian prudence, and their reward in the final victory of faith. Surely all these should be deemed great privileges, and the profession should be highly esteemed that offers them, when we consider how vast are the issues that depend upon our conduct in this fragment, this poor beginning, of our endless life, and how much we allow our conduct to be influenced by the circumstances amongst which we live.

"Now let me recount to you the good things that your profession offers freely. Competency of living; the society of educated men; blessings from the poor; recompense, with gratitude, from the rich; boundless fields for intellectual exercise; access to the richest stores of knowledge 'for the glory of the Creator, and the relief of man's estate ;' daily inducements to the exercise of the highest Christian virtues. Gentlemen, all these are before you, and their price is devotion to your duty."-Introductory Leclure, delivered at the Opening of the Session at S. Bartholomew's Medical College. By Jumes Paget, F.R.S. ('Lancet,' Oct 10).

\title{
The Removal of S. Thomas's Hospital.
}

"The mutual struggles between the Governors of St. Thomas's Hospital, the public, the united and divided parishes on the south side of the Thames, the Governors of Bethlehem Hospital, the Metropolitan Board of Works, and everybody who could get hold of a corner of interest in the matter, seem likely at last to bave been finally decided. A general Court of Governors, held on Tuesday last, approved an agreement entered into by the Grand Committee with the Metropolitan Board of Works for the purchase of seven acres of ground to be reclaimed from the river at Stangate, and the agreement only awaits the sanction of the Court of Chancery to be finally settled. The public will probably think that the sooner this is done the better. A better site might, no doubt, have been found for the hospital than Stangate. The course which recommended itself to common sense was for S. Thomas's Hospital to remove to the site of Bethlehem, and for Bethlehem to be removed into purer air and larger grounds in the country. Common sense, however, is not to be expected in Grand Committees, and the short-sighted rapacity of the Governors of Bethlehem made such an arrangement impossible. Failing that, and finding that public opinion would not allow them to indulge their singularly original project of a metropolitan hospital in the country, the Grand Committee must have been glad to find 80 good a site as Stangate at their disposal. They must, indeed, have had a troublesome time of it the last nine months. It would be interesting to know the feelings which are entertained by the Grand Committee towards 
the Directors of the South-Fastern Railway Company. To be turned out of their old domain, and to be left to tind seven acres in Londun wherever they could, and, worse than that, to be exposed to incessant petitions, remonstrances, and threats from the parishes of Southwark, to an infinite amount of all sorts of advice, and finally to be handed over to the tender mercies of the Metropolitan Bourd of Works-all this combined can hardly conduce to a state of benevolence towards its authors. Perhaps, indeed, the consideration may explain the otherwise unaccountable fancy of the governors for removing a London charity entirely away from London. They may have wanted to get as far away from the South-Eastern Railway as possible.

"There is not much to complain of in the site they have at last determined on. In some respects it is even better than Bethlehem. We are harily able to judge of it fairly yet, for, in fact, it hardly exists. We associnte the side of the river opposite the Houses of Parliament with filthy mud-banks and smells the reverse of wholesome; and it must be confessed that, as the Thames exists at present, its banks do not seem very eligible sites for a hospital. But it must be remembered that we are steadily and surely freeing the river from its impurities, and when that work is accomplished its banks will enjoy a greater volume of pure air than can be obtained in any other site. The contract with the Metropolitan Board of Works stipulates that the land shall be reclaimed and embanked by the 31 st of December, 1865 ; it will he some time after that before the new hospital is built, and by the time it can be occupied the new drainage scheme ought to be completed, and the embankment of the river considerably advanced. When those two works are successfully carried out there will be few sites so healthy or so pleasant as the river side. The river affords, too, a cheap and easy means of access to the hospital, and the site of the new hospital will be as complete a reproduction as possible of that of the old St. Thomas's at London Bridge."-Times, Nov. 24.

\section{The Charity Commissioners and Bethlehem Hospital.}

Yesterday Mr. Martin, Inspector of Charities, commenced an official inquiry, in the committee-room of Bridewell Hospital, into the foundations, endowments, and objects of Bethlehem and Bridewell Hospitals. The inspector stated that he came there under an order of the Charity Commissioners of England and Wales, to make an official inquiry, not that they had any reason to suspeet that anything was wrong, but in the simple performance of the duties of their office. Although he beld an order to inquire into Bridewell as well as Bethlehem, he should at present confine his inquiry to Bethlehem Hospital. He had a very strong opinion as to the policy of releasing their Lincolnshire estate, which was a special trust for the permanent maintenance of incurable lunatics, which was now rendered altogether unnecessary by the establishment of lunatic asylums in every county. The admission of so many incurable patients into Bethlehem Hospital not only created a very great expense beyond the funds obtained from their Lincoln. shire estate, but was a bar to the admission of some 1100 or 1200 patients annually. He should collect evidence on that point. Another question upon which he had not yet formed an opinion was the policy of removing Bethlehem Hospital into the country. Upon that he should take the evidence of the governors, the resident physician, and other medical officers. After some remarks upon the question of charities generally, and the frequent misuse of several of them, the public portion of the inquiry was udjourned sine die. In the mean time the inspector will be engaged in 